University of South Florida

DIGITAL COMMONS

Digital Commons @ University of

@ UNIVERSITY OF SOUTH FLORIDA

South Florida

School of Geosciences Faculty and Staff

Publications

School of Geosciences

2021

\title{
Ethical Product Havens in the Global Diamond Trade: Using the Wayback Machine to Evaluate Ethical Market Outcomes
}

Trina Hamilton

State University of New York at Buffalo

Seth Cavello

University of South Florida, cavello@usf.edu

Follow this and additional works at: https://digitalcommons.usf.edu/geo_facpub

Part of the Earth Sciences Commons

\section{Scholar Commons Citation}

Hamilton, Trina and Cavello, Seth, "Ethical Product Havens in the Global Diamond Trade: Using the Wayback Machine to Evaluate Ethical Market Outcomes" (2021). School of Geosciences Faculty and Staff Publications. 2325.

https://digitalcommons.usf.edu/geo_facpub/2325

This Article is brought to you for free and open access by the School of Geosciences at Digital Commons @ University of South Florida. It has been accepted for inclusion in School of Geosciences Faculty and Staff Publications by an authorized administrator of Digital Commons @ University of South Florida. For more information, please contact digitalcommons@usf.edu. 
This is a pre-print version. The final article is available here:

https://doi.org/10.1177\%2F0308518X211029661

\section{Citation:}

Hamilton, T. and S. Cavello. 2021. Ethical product havens in the global diamond trade: Using the Wayback Machine to evaluate ethical market outcomes. Environment and Planning A: Economy and Space. https://doi.org/10.1177\%2F0308518X211029661 


\title{
Ethical product havens in the global diamond trade: Using the Wayback Machine to evaluate ethical market outcomes
}

\begin{abstract}
Who benefits from ethical product markets? While most ethical products (e.g. fair trade and ecocertified products) are intended to benefit marginalized communities and vulnerable ecosystems, the reality is that the geographic preferences exhibited by so-called ethical markets may, in fact, reinforce global inequities rather than remedy them. It can be difficult to evaluate the outcomes of ethical product markets, however, because we are often limited to data from a small number of industries with widely-used standards and certifications. This research pilots a new methodology, using an online archive - the Wayback Machine, to evaluate shifts in countries' ethical market share, focusing on the evolution of the ethical diamond market over the past 30 years. The ethical diamond market is an interesting case because it began specifically as a competition among countries of origin, with Canadian officials and diamond producers trading on Canada's reputation to position Canada as an ethical product haven in opposition to conflict diamonds from Africa. Yet, Canada's early ethical monopoly has been contested on multiple fronts, and this article focuses on the following questions: To what extent has the contestation over Canada's ethical monopoly actually changed the ethical diamond market? Specifically, how much market share have different ethical alternatives gained and lost over time? And, what does this tell us about the governance and development outcomes of the market? The results show that while the market has diversified over time, it is still largely not benefiting the most marginalized diamond producing countries and communities.
\end{abstract}

Keywords: ethical product havens; governance; international trade; diamonds; Wayback Machine

\section{Introduction}

Who benefits from ethical product markets? Is ethical consumerism really the win-win for consumers and marginalized producers that it is sometimes touted to be (e.g. Micheletti and Stolle, 2006)? As Popke (2006: 508) explains, "For most commentators, ethical trade is neither an unambiguous moral good, nor a simplistic and insincere form of marketing or commodification. It is, rather, a set of institutionalized practices that, from the perspective of ethics and responsibility, offer both opportunities and challenges."

While some might measure the success of a so-called ethical product market by growth in total sales or number of production sites covered by social or environmental standards, it's also important to evaluate exactly which places are covered, and how competitive dynamics alter the production landscape over time. One of the purported opportunities offered by ethical markets is the potential for marginalized countries and communities to benefit from increased market access and the ethical premiums associated with products with enhanced social and environmental credentials, thereby providing an alternative to "race to the bottom"-style development. On the 
other hand, a key challenge to this market access optimism is the reality that the geographic preferences exhibited by so-called ethical markets may, in fact, reinforce global inequities rather than provide a new economic development opportunity for the disenfranchised (Nel et al., 2007: 126). Indeed, trends in the certified forest products market reveal that high-income countries in the Global North have the largest shares of certified forests (Abrams et al., 2018).

One of the problems with this research, however, is that most of what we know about these trends comes from a small range of industries, largely studies of fair trade products, forest certification, and carbon credit markets (e.g. Abrams et al., 2018; Atela et al., 2014; Auld 2010; Bidwell et al., 2018; Corbera and Brown, 2014). The goal of this article is to expand our understanding of the evolution of ethical product markets over time and the associated shifts in the geographies of ethical production by looking at an industry that does not yet have a widelyadopted set of fair trade or ethical production standards, namely, the ethical diamond market. The ethical diamond market is an interesting case because the ethical sub-market developed specifically as a competition among countries of origin, with Canadian officials and diamond producers trading on Canada's reputation for good governance, as well as utopian visions of a pristine Arctic landscape to position Canadian diamonds as the most ethical choice. This particular "geographical imaginary" (Gregory, 2009) was described by an industry analyst as follows: "Canada's positive image became part of our branding strategy ... Canada, renowned for vast open spaces, pure driven snow and pristine beauty is now helping the generic Canadian diamond to be recognized internationally" (Morris, 2005). On the other hand, just as countries' reputations for product quality can shift over time, so too can their reputations as ethical production spaces. In the case of diamonds, Canada's ethical monopoly is being challenged on multiple fronts, including by those who argue that the market should be serving the most marginalized diamond producing countries and communities. In order to understand the governance and development impacts of ethical product markets, we need to look beyond the evolution of a single firm or place, and understand the competitive dynamics and shifting positionalities of different ethical production sites. This article focuses on the following questions: (1) To what extent has the contestation over Canada's ethical monopoly actually changed the ethical diamond market? Specifically, how much market share have different ethical alternatives, including Canadian diamonds, gained and lost over time? And, (2) What does this tell us about the governance and development outcomes of the market?

In order to answer these questions, we created a database of self-described ethical diamond retailers, and used an online archive (the Wayback Machine) to identify the countries of origin and other ethical diamond types (e.g. lab-created diamonds) that each firm sold and promoted on their websites each year between 1990 and 2019. This method allowed us to measure what we call the "discursive market share" for each country of origin and other ethical diamond types, a proxy measure that is useful in the absence of other measures of market share such as value or volume sold, and that can be applied to other industries as well.

The article proceeds as follows: First, we define ethical product markets and situate our research within the broader governance literature on social and environmental standards. Then, we describe in more detail the ethical diamond market and how it has evolved since the late 1990s 
when public awareness of conflict diamonds from countries such as Angola and Sierra Leone coincided with the marketing of new diamond sources from Northern Canada. We then describe our research methodology and the findings from our analysis that reveal significant shifts in discursive market share over time, with Canada's early ethical monopoly being superseded by a diversification of ethical orientations and production spaces. Finally, we conclude with a discussion of the implications of these market shifts, including the difficulties of making the ethical diamond market work for those most marginalized by diamond conflicts and traditional power players.

\section{Ethical product markets and ethical product havens}

Before proceeding, it is important to define ethical product markets. Building on Crane (2001: 362), we define "ethical" products as those for which social and environmental considerations are central to their marketing and/or to consumer choice. Similarly, Clarke et al. (2007: 233) define ethical consumption as seeking "to embed altruistic, humanitarian, solidaristic and environmental commitments into the rhythms and routines of everyday life from drinking coffee, to buying clothes, to making the kids' packed lunch". Rather than focusing on evaluative criteria for parsing the ethical content of the products, Crane's typology focuses on the types of ethical claims that they carry. Whereas some claims relate directly to the product content and production processes, others relate to the product's marketing, or to the ethics of the corporation or country of origin as a whole (Crane 2001: 365). Finally, he points to the inherent relationality of ethical claims, noting that, given their myriad social and environmental entanglements, a product is never completely ethical, but may be conceived as relatively more ethical than others in the same category or ethical related to a specific issue (Crane 2001: 368).

There are many ways to evaluate ethical markets, but the goal of this article is to evaluate the ethical diamond market in terms of its governance outcomes. Nadvi (2008: 324) defines governance as "the framework and institutional structures by which rules (which include laws at one extreme and norms at the other) are set and implemented." Within so-called ethical markets, the rules extend beyond traditional market governance concerns such as contract enforcement and seek to explicitly and directly embed social and environmental values into the market. These additional values are often transmitted and enforced through standards and certifications, including firm-level, industry-wide, and global standards (Angel et al., 2007). These standards may be monitored and implemented internally by firms or industries (so-called voluntary governance), through inter-firm contracts and pressures (global value chain governance), or by third party, multi-stakeholder organizations.

Within industries without widespread certification efforts, or with contested standards and certifications, producers and retailers may end up signaling ethical credentials through country of origin. Country of origin may lead to "drives to buy only home-produced products" or boycotts based on "government policies deemed unacceptable by overseas consumers," such as the antiapartheid boycotts of South African products (Crane 2001, 367). Examples of using country of origin as a positive selection criteria within ethical markets include marketing Canada as an ethical source for diamonds by direct contrast with conflict diamonds from Africa ${ }^{2}$ (Le Billon, 
2006; Schlosser, 2013), and Ecuador's efforts to become known as a sustainable palm oil source (Johnson, 2014). Moreover, there are plenty of examples of the preference for home-produced products discussed by Crane, including a recent study of ethical consumption in South Africa that revealed the growing strength of the Proudly South African brand (McEwan et al., 2015). There is now even a whole journal (Place Branding and Public Diplomacy) dedicated to studying "the rapidly-expanding practice of place branding," 3 along with a growing cadre of nationbranding policy advisors. One such advisor, Simon Anholt, has argued that place-based rebranding efforts are "powerful tool[s] for economic development, and could make a very worthwhile contribution to the growth of the places which need it most" (Anholt, 2005: 1).

Yet, while advisors such as Anholt are bullish on nation-branding, there is increasing attention being paid by governance scholars to the question of who actually benefits from ethical product markets (Abrams et al., 2018)? Indeed, many studies of mainstreaming within ethical product markets (including fair trade and eco-markets) have revealed spatial and temporal patterns favoring wealthier countries and larger firms. These countries may eventually become what we call ethical product havens - production spaces favored for their ethical credentials in end markets, to the relative exclusion of other production sites. We use the term ethical product haven in the same way that the term tax haven is used to refer to a space that is a purported haven for capital, but widely seen as creating broader social ills, including diminishing the public coffers of other countries and jurisdictions. In terms of certified forest products, "in contrast to what many certification pioneers had hoped, the vast majority of forest acres certified to date are located in countries of the Global North, particularly the US, Canada, Western Europe, Russia, and the former Soviet states" (Abrams et al., 2018: 68-69). In other words, the market is largely not serving its original goal of stemming deforestation of tropical rainforests (see also Cashore et al., 2007). Research on certified agricultural products has identified cases where countries have developed significant export markets for organic or fair trade products (e.g. bananas from the Dominican Republic and coffee from Peru and Mexico), despite not having "had a historically important presence in conventional markets" for those products (Bidwell et al., 2018; also Auld, 2010), but none of these studies has followed market shifts over the long term to determine how long-lasting they are. As Bair and Werner (2011: 989) argue, "changing geographies of global production reflect moments of inclusion and exclusion," and we would argue that ethical product markets are no different from conventional markets in the need to better understand "those processes by which regions and actors become disconnected or expulsed from commodity chains that may be incorporating new regions and actors elsewhere" (see also Bridge, 2004 re: extractive industries).

One reason behind changing patterns of inclusion and exclusion within ethical markets is the ongoing contestation over specific social and environmental goals. A significant body of recent research has addressed the diversity and fuzziness of consumer desires and personal narratives that motivate ethical consumption (Autio et al., 2009; Benson and Fischer, 2007; Brach et al., 2018; Carrigan et al., 2005; Friedberg, 2003; McEwan et al., 2015). This diversity provides a market for many different types of ethical "augmentation" (Crane, 2001; see also Bryant and Goodman, 2004; Goodman, 2010). This is one of the reasons why social and environmental standards tend toward divergence (Nadvi, 2008; Nadvi and Wältring, 2004). In terms of the ethical havens argument, it's possible for this contestation and divergence to create space for a larger array of production sites to be incorporated into the ethical market, whether in terms of country of origin or specific types of ethical criteria (environmental versus social criteria, for 
instance). On the other hand, another reason for disarticulations (or lack of integration) is that market-enabling imperatives may overtake regulatory ones (Hamilton, 2011: 712; see also Levy and Prakash, 2003). Bidwell et al. (2018) refer to this process as "recommodification," illustrating that cost is king even in ethical markets, and particularly for mainstreaming ethical markets. In the case of certified forest products, cost calculations have ultimately favored countries where "compliance with basic environmental and labor laws is already institutionalized and where land tenure tends to be highly formalized and relatively uncomplicated" and "certification represents a less radical change" from business as usual (Abrams et al., 2018). In other words, while ethical markets and certification programs are often framed as alternatives to state regulation, the "winners" in these markets are often producers from countries with corresponding pre-existing regulatory foundations and nation-branding.

Overall, the literature shows that in order to understand the true potential (and limitations) of ethical product markets to actually achieve their original goals, whether they be ecological and/or development goals, we need to understand how they evolve over time, including processes of inclusion and exclusion of different countries of origin.

\section{Ethical diamonds: The "beyond Kimberley" market}

The emergence of the ethical diamond market can be traced to the late 1990s, when the issue of blood (aka conflict) diamonds from countries such as Angola and Sierra Leone was gaining traction as a global human rights issue. Reports such as Global Witness's A Rough Trade linked the diamond trade with civil war and violence, and directly criticized industry giant DeBeers for buying and re-selling Angolan diamonds. The emotional link between diamonds and love forged by the wildly successful (and widely criticized) "a diamond is forever" marketing campaign ${ }^{4}$ was contested by a new emotional association between diamonds and conflict (Falls, 2011; Le Billon, 2006). There were several responses to the conflict diamond issue, including the Kimberley Process Certification Scheme (KPCS), a UN-led, multi-stakeholder initiative developed "to prevent the flow of conflict diamonds" ". "The scheme establishes a voluntary system requiring all participants not to trade in rough diamonds with nonparticipating countries, according to principles backed by national legislation, peer review missions, and the possibility of exclusion" (Le Billon, 2008: 364).

There is, however, widespread dissatisfaction with the Kimberley Process. Criticisms include questions over signatory governments' capacities (and will) to secure their diamond exports and imports and prevent smuggling, as well as the limited definition of what counts as a conflict diamond. While the Kimberley Process targets "rough diamonds used by rebel movements to finance wars against legitimate governments, ${ }^{6}$ " it does not address the many other social and environmental concerns surrounding the diamond industry.

Canada's first diamond mine started operating in the Northwest Territories in 1998, the same year that Global Witness's A Rough Trade report was published. The release of the Hollywood blockbuster film "Blood Diamond" in 2006 fueled a new round of media attention to the issue, and Canada quickly cornered the so-called ethical diamond market (Le Billon, 2006; Schlosser, 
2013). In 2008, the minister of Industry, Tourism and Investment for the government of the Northwest Territories argued that Canadian diamonds "are not 'blood' diamonds like the ones used to finance wars and other conflicts in Africa." Referring directly to Canada's nationbranding efforts, he continued, "'We've taken advantage of that, whereby we promote them as Canadian diamonds and our government issues certificates to attest to the fact that these diamonds are mined, cut and polished in Canada and the Northwest Territories, and there's no possibility they're conflict diamonds in any way, shape or form'."'7

Yet, there has been growing dissatisfaction with Canada's ethical monopoly. A range of studies have set out to determine whether Canadian diamond production sites live up to their ethical reputation and to explain the distortions of Canadian diamond marketing (Bielawski, 2004; Missens et al., 2007; Whitelaw et al., 2009). Some analyses attempt to reinscribe Canadian diamonds as "rogue diamonds" with significant negative impacts on the environment and indigenous cultural survival (Bielawski, 2004). Other observers question why Canada and not Africa should benefit from the ethical diamond trade ${ }^{8}$. In the absence of a widely adopted fair trade or sustainability standard, the market has diversified largely through competing national claims, with a range of new favored production sites, from Botswana to Australia and Russia countering Canada's dominance. The marketing messages vary, with some sources (e.g. Australia) being positioned largely as additional Canadas (i.e. "good governance" countries with labor, environmental and other laws securing the diamonds' ethical credentials), while others (e.g. Botswana) are also touted as development success stories. It should be noted that most of these competitors are also large, industrial commodity-producing nations. In the case of diamonds, this means they are dominated by large-scale industrial extraction from kimberlite pipes ('big hole' mining) rather than small- and medium-scale alluvial mining (can be industrialized or excavation by artisanal diggers).

As Le Billon $(2008,366)$ notes, "The idealization of industrially mined Canadian [and increasingly other industrially mined] diamonds over artisanally mined African diamonds ... risks marginalizing a major export commodity for several African economies and aggravating the situation of artisanal miners." This has led several ethical diamond retailers, jewelry designers and consultants to describe fairly traded, artisanal diamonds from countries such as Sierra Leone as their ideal, ${ }^{9}$ although an ideal that almost impossible to source because of the highly complicated and opaque structure of the global diamond trade. At the same time, advances in synthetic diamond production have led to a steady rise in lab-created diamonds ${ }^{10}$ being marketed as an ethical alternative that circumvents the 'big hole' problem of industrial mining and the human rights and traceability concerns of alluvial mining. Similarly, recycled and antique diamonds ${ }^{11}$ are also increasingly marketed as ethical alternatives that do the least harm. All of these different diamond sources represent what we might call the "beyond Kimberley" market. They are all marketed based on social and/or environmental considerations and claim to go beyond the Kimberley Process' conflict-free definition.

The ethical diamond market provides an interesting opportunity for looking at the evolution of an ethical market precisely because it has yet to generate any widely-adopted set of standards beyond the Kimberley Process Certification Scheme (KPCS). The ethical diamond market has clearly evolved since Canada first entered the marketplace in the late 1990s. Yet, the question 
remains, to what extent has the contestation over Canada's ethical monopoly actually changed the ethical diamond market? Specifically, how much market share have different ethical alternatives, including Canadian diamonds, gained and lost over time? One of the problems in trying to answer this question is a lack of data. The majority of the data on ethical market trends over time come from specific certifications bodies, whether it be the various fair trade or ecocertifications such as the Forest Stewardship Council (FSC). Since there is no repository for data on non-certified ethical product sales and trade patterns, it is hard to evaluate change in the market over time. One promising avenue for analysis, however, is to reconstruct the evolution of the market via the Wayback Machine, an online repository of archived versions of websites.

\section{Backwards ethics: Reconstructing market evolution with digital archives}

\section{The Wayback Machine and the social sciences}

The Wayback Machine is the public portal for The Internet Archive, "a 501(c)(3) non-profit that was founded to build an Internet library. Its purposes include offering permanent access for researchers, historians, scholars, people with disabilities, and the general public to historical collections that exist in digital format." 12 The Wayback Machine allows you to type in a URL and access archived versions of the website.

The largest share of academic work using the Wayback Machine is within the information technology field, but Arora et al. (2016) find that it is increasingly being used within the social sciences as a source for quantitative data. They argue archived websites may substitute for survey data, for instance, particularly given the widespread survey fatigue that many researchers have identified. They might also help overcome some of the well-known limits to self-reporting, including problems with recall and self-reporting bias. Some examples of research using the Wayback Machine as a source of data on firm behavior include studies of the evolution of firms' websites, ecommerce and social media activities (Curty and Zhang, 2012; Hashim et al., 2007), innovation and commercialization processes (Li et al., 2018; Youtie et al., 2012), and public relations and corporate responsibility strategies (Peeters and Gilmore, 2015; Smith, 2015). These firm behaviors have also been correlated to performance measures such as profitability and firm survival (e.g. Blazquez et al., 2018).

While several studies have validated the use of the Wayback Machine to evaluate website evolution (Murphy et al., 2007), there are still limitations to working with Wayback Machine data. One concern is the uneven frequency and depth of archiving, with some websites and subpages archived more often than others. Ainsworth et al. (2016) found that, despite the appearance of presenting a snapshot in time, most archived sites are not "temporally coherent", with different parts of the site archived at different times. This is of particular concern if the goal is to generate panel data on firm or website characteristics that can then be correlated with performance metrics for that same time period. While such limitations need to be accounted for in each study's research design, they do not diminish the overall utility of the resource, particularly where no other alternative exists for making "across-time comparisons." 


\section{Reconstructing the evolution of the ethical diamond market}

This particular analysis is part of a larger study of the evolution of the ethical diamond market, including event ethnography at jewelry trade shows, and interviews with diamond retailers, jewelry designers, and industry analysts and consultants. One goal of the project is to document changes over time in the countries of origin of diamonds marketed as ethical. Given that there was some evidence of the contestation of Canada's early monopoly of the market, we wanted to evaluate how much market share different ethical alternatives, including Canadian diamonds, gained and lost over time, as one measure of what interests and goals the market is serving. Since it is not possible to get data on the exact number, carats, or dollar value of ethical diamonds sold by country of origin, we had to resort to a proxy measure for market share. We decided to assess the number of retailers (including jewelry designers who sell their own creations as well as multi-brand retailers) offering diamonds from each country of origin for each year since the origin of the current ethical diamond market in the late 1990s (following the media attention to the conflict diamond issue) until 2019. ${ }^{13}$ Given the lack of alternate data sources, we were limited to those retailers with a web presence, although several interviewees explained that a web presence was essential within the niche ethical market because their business relied on a national and sometimes international customer base willing to pay ethical premiums and looking specifically for ethical credentials. We might think of this proxy as a "discursive market share," then, since it represents the number of retailers buying into (and selling) different narratives of ethical diamond production rather than the total volume or value sold from each country of origin. It should also be noted that the focus of this study is on the ethical diamond market in the United States, the United Kingdom, and Canada, so we limited our analysis to retailers with a brick and mortar presence in these countries, and to online retailers with information about shipping to at least one of these countries. The US is still the largest diamond market by far, accounting for about $90 \%$ of diamond jewelry sales, but sales are growing in Asia, with China now accounting for about $10 \%$ of sales. That said, the key marketing campaigns in Asia seem to follow the early marketing in the US and Europe, tying diamonds to love, whereas US marketing is focused on countering synthetic (aka lab-created or lab-grown) diamond growth. ${ }^{14}$

The first step was to identify the retailers. We developed a group of search terms based on our background research into the industry, and added more as we they came up in our searches of retailers and ethical jewelry events and advocacy organizations. The following search terms were used to search Google, Twitter, and the Factiva news database: ethical diamonds, fair trade diamonds, eco diamonds, development diamonds, sustainable diamonds, green diamonds, clean diamonds, and conflict free diamonds. ${ }^{15}$ Recognizing that search results vary depending on location and that given our location in the US we might be missing retailers from Canada and the UK, we conducted additional searches for ethical diamonds Canada, and ethical diamonds UK. Since several of the search terms (ethical diamonds, conflict free diamonds) generated a large number of returns (tens of thousands), a search was deemed finished after five consecutive pages of irrelevant material. We also searched the membership and participant lists for several key ethical jewelry and ethical diamond initiatives (past and present), including the Madison Dialogue, the Jewelry Industry Summit (JIS), and the Responsible Jewellery Council (RJC). We then removed any retailers that were using Kimberley Process compliance as their sole ethical 
credential since this is supposed to be standard operating procedure and not a distinguishing characteristic of an ethical retailer. We also removed any retailers that claimed to go beyond the Kimberley Process but did not have any details or country of origin information, and we ended up with 168 self-described ethical retailers.

After capturing the country of origin information for 2019, the URL for each retailer website was entered into the Wayback Machine, and diamond origin information was captured for each year that the website was archived. As noted above, the Wayback Machine captures websites with different frequencies, so we used the earliest capture for each year. That said, different sub-pages might not have been captured on the same date, so the data represents the evolution of each retailers' ethical diamond offerings over time rather than a precise record of the specific dates that these offerings changed. And, unlike some other studies described above, we were not correlating the Wayback Machine data with other data that would necessitate more precision in the timeline. Website formatting also dictated what type of information could be captured, particularly in the earlier years of website archiving, although this was only a problem for a small number of websites.

\section{The Dimming of Canada's Halo?}

The questions that we started out with were: To what extent has the contestation over Canada's ethical monopoly actually changed the ethical diamond market? And, specifically, how much market share have different ethical alternatives, including Canadian diamonds, gained and lost over time? Figure 1.0 and Table 1.0 illustrate the growth of the "beyond Kimberley" diamond market over time, starting with 2 firms in 2002 and growing to 168 firms in $2019 .{ }^{16}$ What started as an exclusively Canadian market in the early 2000s has rapidly diversified over the past decade. This representation can be somewhat misleading, however, as it does not mean that these were necessarily new diamond sources or represent new conditions of production. Rather, in many cases, this growth represents a rebranding of existing diamond sources. Moreover, this data represents claims about country of origin, and industry insiders (including multiple interviewees) noted that there is a certain amount of misrepresentation of origins. That said, the goal of the discursive market share metric is to identify shifts in how ethical diamonds are defined and conceived over time, and this data shows a diversification of ethical orientations over time. Figure 1.0 represents this growth as layers of new ethical diamond sources emerging gradually at first, but then ultimately building out a multi-faceted market. It is interesting to note that the first three layers added to the Canadian origin stones were lab-created, recycled, and Russian origin stones. It's clear that the early ethical market was focused on avoiding Africa. Over time, and largely as a result of the promotional work of the industry-backed Diamond Empowerment Fund (DEF), a range of African diamond sources, from large-scale industrialized giants such as Botswana to smaller-scale players such as Lesotho, get incorporated into the ethical market. Finally, the most recent entrant into the ethical market is Australia, emerging in 2010. There are several possibilities for this delayed incorporation of Australia, including geographic distance (since our focus is on the Canadian, US and UK markets, it's possible that there was simply less familiarity with Australian diamonds on the part of consumers), and the fact that as there was a 
mainstreaming of the ethical market, demand for a wider range of products grew, including the relatively unique colored stones from. The nature of these shifts is discussed in more detail below.

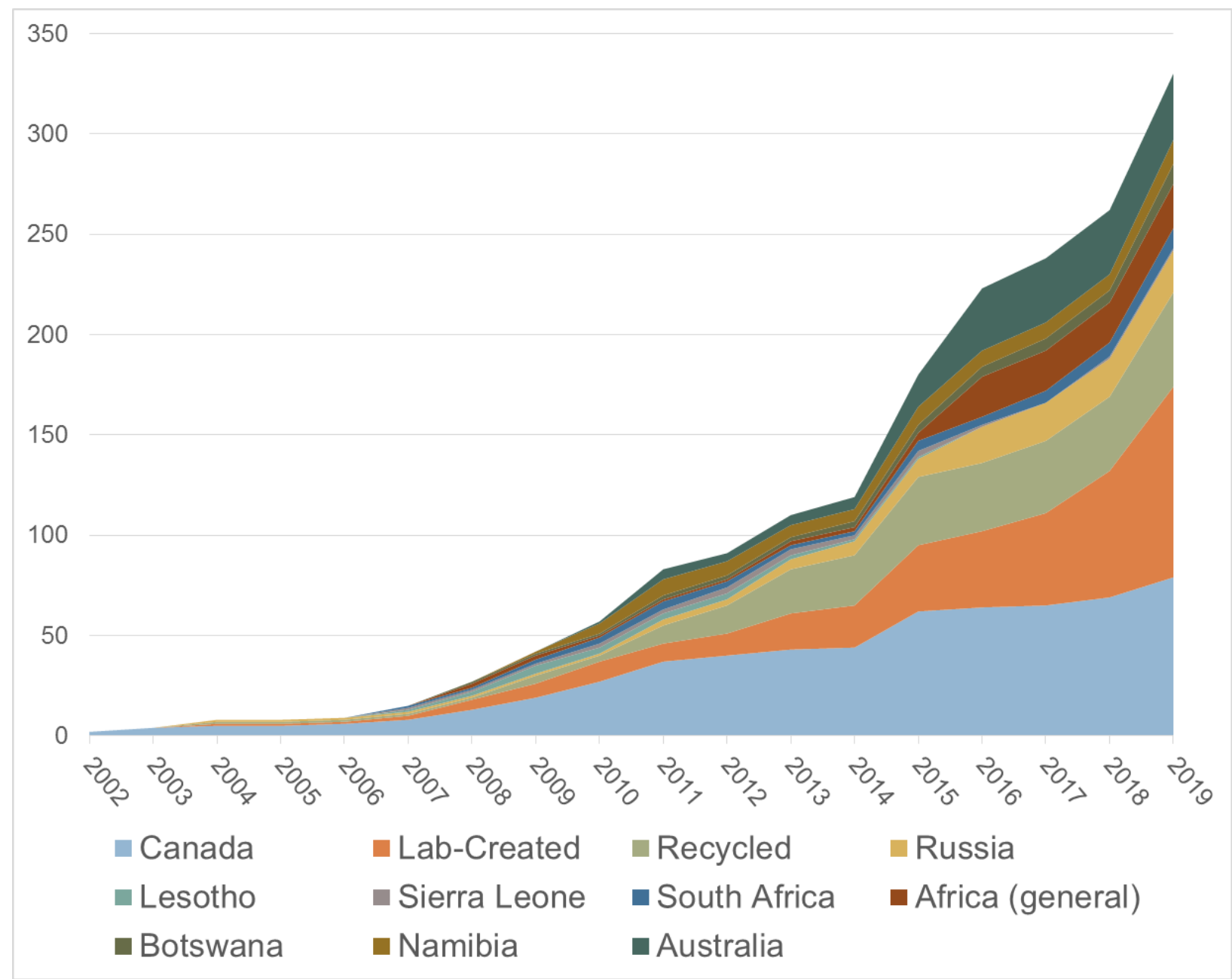

Figure 1.0 - Number of retailers offering each ethical diamond type per year

Figure 2.0 and Table 1.0 provide better representations of the answer to the second question, about how much market share different ethical alternatives have gained and lost over time. Figure 2.0 represents one view of discursive market share. It represents each diamond origin's share of the total ethical diamond offerings for that year (i.e. the sum of each retailer $\mathrm{x}$ the retailer's total number of ethical diamond sources). Table 1.0 provides a slightly different version of discursive market share - the number and percentage of retailers offering each diamond type per year. Taken together, the data shows a clear, precipitous decline in Canada's ethical monopoly, even as the overall number of retailers marketing Canadian diamonds as ethical continues to increase (see Figure 1.0 and Table 1.0). Indeed, Table 1.0 shows that 2019 marked a clear turning point, with lab-created diamonds overtaking Canadian diamonds in terms of 
discursive market share. In other words, the contestation of Canada's status as the sole ethical alternative has clearly changed the ethical diamond market, and the tropes used to sell Canadian diamonds are not unassailable. The data also reveals some interesting market blips, with ethical diamond offerings from Lesotho and Sierra Leone appearing and then disappearing (and reappearing in the case of Sierra Leone). As will be discussed below, these blips represent fleeting connections between specific mining cooperatives and ethical diamond retailers, whereas the contestation of Canada's monopoly has largely favored large, industrialized mining companies from Russia, South Africa, Botswana, Namibia and Australia, as well as a rapidly increasing number of lab-created producers.

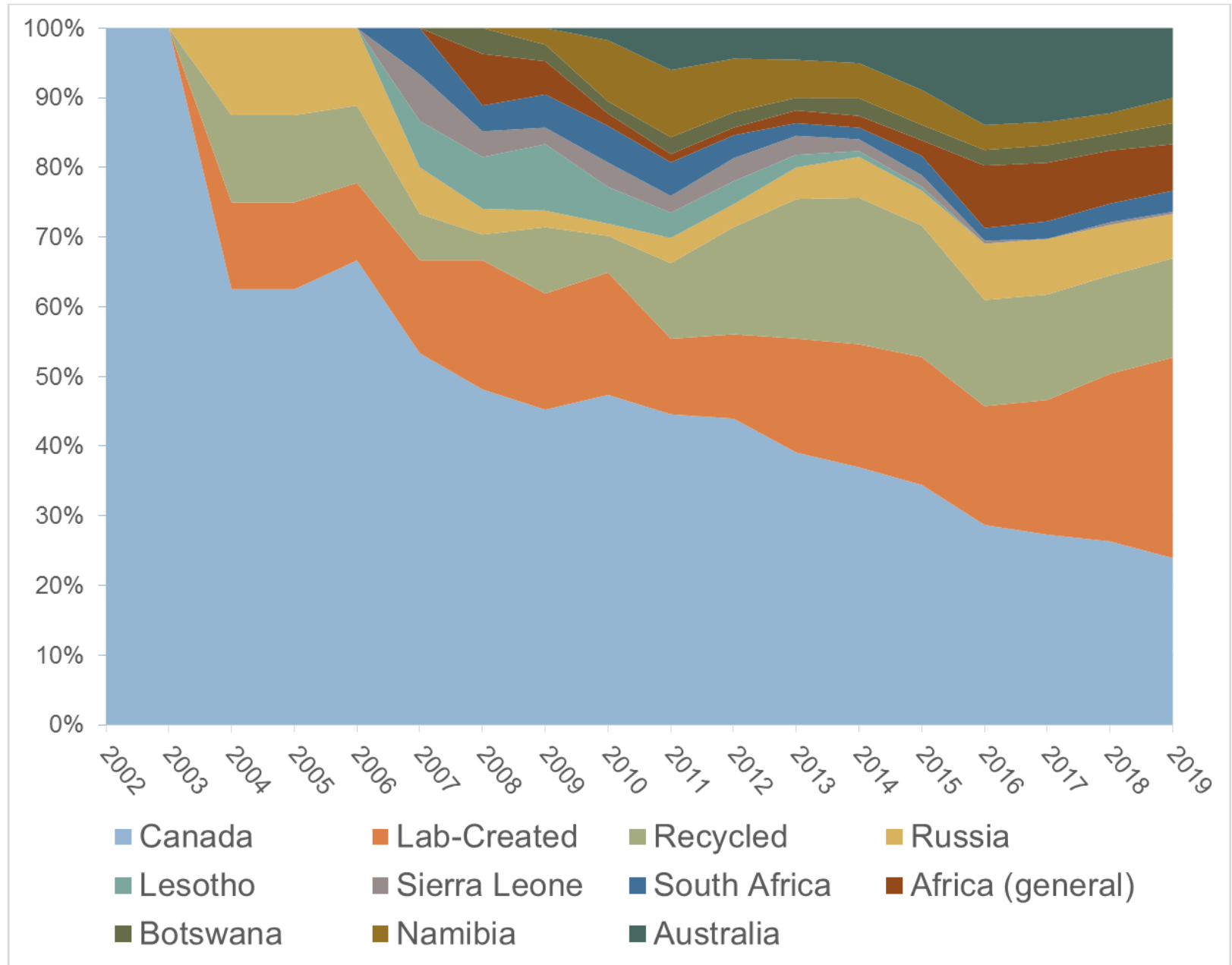

Figure 2.0 - Discursive market share by diamond type per year 
Table 1.0 - Number (and percentage) of retailers offering each ethical diamond type per year

\begin{tabular}{|c|c|c|c|c|c|c|c|c|c|c|c|c|}
\hline & Canada & $\begin{array}{c}\text { Lab- } \\
\text { Created }\end{array}$ & Recycled & Russia & Lesotho & $\begin{array}{l}\text { Sierra } \\
\text { Leone }\end{array}$ & $\begin{array}{l}\text { South } \\
\text { Africa }\end{array}$ & $\begin{array}{c}\text { Africa } \\
\text { (general) }\end{array}$ & Botswana & Namibia & Australia & $\begin{array}{c}N \\
\text { firms }\end{array}$ \\
\hline 2002 & $2(100 \%)$ & 0 & 0 & 0 & 0 & 0 & 0 & 0 & 0 & 0 & 0 & 2 \\
\hline 2003 & $4(100 \%)$ & 0 & 0 & 0 & 0 & 0 & 0 & 0 & 0 & 0 & 0 & 4 \\
\hline 2004 & $5(71 \%)$ & $1(14 \%)$ & $1(14 \%)$ & 1 (14\%) & 0 & 0 & 0 & 0 & 0 & 0 & 0 & 7 \\
\hline 2005 & $5(71 \%)$ & $1(14 \%)$ & $1(14 \%)$ & $1(14 \%)$ & 0 & 0 & 0 & 0 & 0 & 0 & 0 & 7 \\
\hline 2006 & $6(75 \%)$ & $1(13 \%)$ & $1(13 \%)$ & $1(13 \%)$ & 0 & 0 & 0 & 0 & 0 & 0 & 0 & 8 \\
\hline 2007 & $8(62 \%)$ & $2(15 \%)$ & $1(8 \%)$ & $1(8 \%)$ & $1(8 \%)$ & $1(8 \%)$ & $1(8 \%)$ & 0 & 0 & 0 & 0 & 13 \\
\hline 2008 & $13(59 \%)$ & $5(23 \%)$ & $1(5 \%)$ & $1(5 \%)$ & $2(9 \%)$ & $1(5 \%)$ & $1(5 \%)$ & $2(9 \%)$ & $1(5 \%)$ & 0 & 0 & 22 \\
\hline 2009 & 19 (56\%) & $7(21 \%)$ & $4(12 \%)$ & $1(3 \%)$ & $4(12 \%)$ & $1(3 \%)$ & $2(6 \%)$ & $2(6 \%)$ & $1(3 \%)$ & $1(3 \%)$ & 0 & 34 \\
\hline 2010 & 27 (63\%) & $10(23 \%)$ & $3(7 \%)$ & $1(2 \%)$ & $3(7 \%)$ & $2(5 \%)$ & $3(7 \%)$ & $1(2 \%)$ & $1(2 \%)$ & $5(12 \%)$ & $1(2 \%)$ & 43 \\
\hline 2011 & $37(65 \%)$ & $9(16 \%)$ & $9(16 \%)$ & $3(5 \%)$ & $3(5 \%)$ & $2(4 \%)$ & $4(7 \%)$ & $1(2 \%)$ & $2(4 \%)$ & $8(14 \%)$ & $5(9 \%)$ & 57 \\
\hline 2012 & $40(63 \%)$ & $11(17 \%)$ & $14(22 \%)$ & $3(5 \%)$ & $3(5 \%)$ & $3(5 \%)$ & $3(5 \%)$ & $1(2 \%)$ & $2(3 \%)$ & $7(11 \%)$ & $4(6 \%)$ & 64 \\
\hline 2013 & 43 (58\%) & $18(24 \%)$ & $22(30 \%)$ & $5(7 \%)$ & $2(3 \%)$ & $3(4 \%)$ & $2(3 \%)$ & $2(3 \%)$ & $2(3 \%)$ & $6(8 \%)$ & $5(7 \%)$ & 74 \\
\hline 2014 & $44(58 \%)$ & $21(28 \%)$ & 25 (33\%) & $7(9 \%)$ & $1(1 \%)$ & $2(3 \%)$ & $2(3 \%)$ & $2(3 \%)$ & $3(4 \%)$ & $6(8 \%)$ & $6(8 \%)$ & 76 \\
\hline 2015 & $62(61 \%)$ & $33(32 \%)$ & $34(33 \%)$ & $9(9 \%)$ & $1(1 \%)$ & $3(3 \%)$ & $5(5 \%)$ & $4(4 \%)$ & $4(4 \%)$ & $9(9 \%)$ & $16(16 \%)$ & 102 \\
\hline 2016 & $64(60 \%)$ & $38(36 \%)$ & $34(32 \%)$ & $18(17 \%)$ & 0 & $1(1 \%)$ & $4(4 \%)$ & 20 (19\%) & $5(5 \%)$ & $8(8 \%)$ & $31(29 \%)$ & 106 \\
\hline 2017 & 65 (58\%) & $46(41 \%)$ & $36(32 \%)$ & $19(17 \%)$ & 0 & 0 & $6(5 \%)$ & 20 (18\%) & $6(5 \%)$ & $8(7 \%)$ & $32(28 \%)$ & 113 \\
\hline 2018 & $69(53 \%)$ & $63(49 \%)$ & $37(29 \%)$ & $19(15 \%)$ & 0 & $1(1 \%)$ & $7(5 \%)$ & 20 (16\%) & $6(5 \%)$ & $8(6 \%)$ & $32(25 \%)$ & 129 \\
\hline 2019 & 79 (47\%) & $95(57 \%)$ & $47(28 \%)$ & $21(13 \%)$ & 0 & $1(1 \%)$ & $10(6 \%)$ & $22(13 \%)$ & $10(6 \%)$ & $12(7 \%)$ & $33(20 \%)$ & 168 \\
\hline
\end{tabular}

There are, then, several different processes of contestation underway. Table 2.0 sets out, in broad strokes, the varied ethical orientations and narratives surrounding each diamond type. ${ }^{17}$ On the one hand, there has been a concerted effort to advance a development diamond narrative that promotes diamonds as a development engine, particularly in Africa. The industry-backed Diamond Empowerment Fund (DEF) (launched in 2007 and now operating as Diamonds Do Good $)^{18}$ has been particularly active. Instead of depopulated images the Canadian North, the Diamonds Do Good and related marketing campaigns have focused on "modernization" narratives and images, with significant emphasis on "beneficiation" projects, or the capture of added value from the diamond commodity chain through sorting, cutting and polishing activities. In some ways, this has been an effort to counter Canada's "doing the least harm" branding, focused on remoteness and a generalized good governance brand, with a "doing the most good" development branding. ${ }^{19}$ In other words, there has been some diversification of the ethical appeals and associated geographic imaginaries within the broader ethical diamond market. There 
have been limits to the success of this messaging, however. While Botswana is the second largest diamond producer in the world (see Table 3.0), it trails Australia (as well as lab-created and recycled diamonds) in terms of discursive market share within the ethical diamond market (see Figure 2.0 and Table 1.0). Racist colonial legacies and geographical imaginations are undoubtedly part of the story (Schlosser 2013). Traceability is another key factor. As with many ethical markets, traceability - i.e. the ability to provide end consumers with the country of origin for the rough diamond(s) that are transformed into their jewelry, has become an overriding preoccupation (Hilson et al., 2016; Raynolds, 2009; Schroeder, 2010). The Diamond Trading Company (DTC), DeBeers' sales and distribution arm, employs an aggregation model, wherein diamonds from their mines in Botswana, Canada, Namibia and South Africa are combined and then sorted into allotments for customers. ${ }^{20}$ Until recently, DeBeers did not even allow customers to disclose that their diamonds came from DeBeers mines. In response to demands from stakeholders such as the large luxury retailer Tiffany's, DeBeers is now allowing customers to "identify diamonds purchased from De Beers as 'DTC diamonds'."21 DeBeers and Russian diamond giant Alrosa are also partnering on TRACR, a blockchain platform designed to track diamonds from mine to market. ${ }^{22}$

Table 2.0 - Ethical diamond orientations

\begin{tabular}{|c|c|c|c|}
\hline Origin/Type & \multicolumn{2}{|c|}{ Primary ethical appeal } & Ethical boundaries \\
\hline $\begin{array}{l}\text { Canada, Russia, } \\
\text { Australia }\end{array}$ & \multirow{3}{*}{$\begin{array}{l}\text { Doing the } \\
\text { least harm }\end{array}$} & Good governance & Country \\
\hline Lab-created & & Sustainability & Category \\
\hline Recycled & & Sustainability & Category \\
\hline $\begin{array}{l}\text { Botswana, Namibia, } \\
\text { South Africa }\end{array}$ & \multirow{3}{*}{$\begin{array}{l}\text { Doing the } \\
\text { most good }\end{array}$} & $\begin{array}{l}\text { Good governance and } \\
\text { economic development }\end{array}$ & Country \\
\hline $\begin{array}{l}\text { Africa (general } \\
\text { category) }\end{array}$ & & Economic development & Continent \\
\hline Lesotho, Sierra Leone & & Economic development & Cooperative \\
\hline
\end{tabular}

Table 3.0 - 2019 rough diamond production by volume and value

\begin{tabular}{|l|r|r|}
\hline Country & Volume (cts) & Value (USD) \\
\hline Russian Federation & $45,271,212.01$ & $\$ 4,116,599,277.57$ \\
\hline Botswana & $23,687,013.00$ & $\$ 3,434,616,885.00$ \\
\hline Canada & $18,638,302.05$ & $\$ 1,697,446,304.57$ \\
\hline Democratic Republic of Congo & $14,158,422.34$ & $\$ 226,116,229.79$ \\
\hline Australia & $12,998,986.70$ & $\$ 159,194,720.91$ \\
\hline Angola & $9,149,746.23$ & $\$ 1,266,223,479.17$ \\
\hline South Africa & $7,180,952.00$ & $\$ 873,000,997.54$ \\
\hline Zimbabwe & $2,108,261.08$ & $\$ 141,448,511.00$ \\
\hline Namibia & $2,018,098.69$ & $\$ 1,009,548,119.20$ \\
\hline Lesotho & $1,113,525.65$ & $\$ 290,104,991.28$ \\
\hline
\end{tabular}


Source: Kimberley Process Rough Diamond Statistics:

https://kimberleyprocessstatistics.org/public statistics

While the details of the narratives used to mark different countries of origin as ethical production spaces may vary, there are some important similarities amongst these diamond sources. As noted above, they are all large-scale, industrial mining countries. According to a recent global diamond industry report, the top 5 players in diamond exploration and production control $70 \%$ of the market, ${ }^{23}$ and it seems clear that these mining powerhouses are moving to make sure that all of their diamonds are considered ethical. Over time they have succeeded in coding their production spaces as ethical simply because they are industrialized, formalized, and increasingly traceable to a country of origin. Studies of other global production networks have also shown that it is important to understand the "dynamics of concentration and centralization" that affect social and environmental governance throughout the industry (Havice and Campling, 2017: 309).

The evolution of the ethical diamond market is not simply a story of power plays by the big industrial miners, however. On the consumer end, while there is some evidence for a diversification of consumers' ethical orientations, mainstreaming of the ethical market also means that quantity, consistency, variety, and cost become key criteria before the ethics. In the words of one interviewee (an ethical jewelry retailer): "We know the 4 critical areas of purchase are price, quality, design, and choice. If you don't, if you're going to buy a ring from me, if you don't qualify on those four, you don't get a sale. Then you've got customer service, customer ambiance, then ethics. They may come to you because of ethics, but it doesn't mean they're going to buy. If you produce just a load of that, they aren't going to buy" (personal interview, 9/14/17). Similar mainstreaming processes have been discussed in terms of fair trade coffee, for instance (Raynolds, 2009; Renard, 2005). These mainstreaming considerations privilege the big industrial miners, as well as the new lab-created diamond manufacturers.

Indeed, lab-created diamonds have become so popular that a whole 6,400 square foot "LabGrown Diamond Neighborhood" was debuted at one of the industry's largest jewelry trade shows in Las Vegas in 2018. According to one of the event organizers, "Price may be the biggest factor in customers' purchasing decisions - synthetic diamonds can cost a third of what natural ones do, according to interviewees - while sustainability and transparent sourcing are close behind." ${ }^{24}$ The rapid ascent of lab-created diamonds within the ethical diamond market is driven by a "do the least harm" narrative that seems to resonate with sustainability-oriented consumers, with a similar positioning of recycled diamonds (see Table 2.0). It seems, then, that Canada's "do the least harm" narrative may have been particularly vulnerable to the lab-created and recycled diamond messaging. In other words, Canada's ethical monopoly was upended by the very same process that it was created by in the first place, by relationality, or marketing itself as not conflict-ridden Africa (Le Billon 2006, 2008; Schlosser 2013). In the case of lab-created diamonds, they are marketed as the new reference point, with everything else falling short (e.g. "No such things as 'ethically sourced' mined diamonds"). ${ }^{25}$ Despite the success of these other alternatives, several interviewees noted that Canadian diamonds were still acceptable alternatives; in other words, although Canadian diamonds no longer monopolize the ethical 
market, they retain a first mover advantage built both on image-making and an easily accessible supply chain. One jewelry designer explained: "With my sourcing I decided I would work primarily with recycled diamonds. ... The original source of each diamond isn't really known, so we don't know, are they conflict diamonds or not? But, they're not adding to the demand. ... That's my primary go to when it's not adding any new environmental impact" (Jewelry designer and retailer, personal interview, 3/30/17). Yet, in a clear example of the interplay between ethics and conventional consumer concerns such as quality and design, they added: "we use Canadian diamonds and those are our standard secondary source if we can't get a recycled one.

...Sometimes with the recycled it can be limited if someone wanted a certain quality, like a very specific quality diamond, and we have to expand the search a little bit. We do Australian -- the champagne diamonds, the colored diamonds from the Argyle mine in Australia" as well (Jewelry designer and retailer, personal interview, 3/30/17).

\section{Blips and Big Market Movements}

As discussed above, the big market movements in the ethical diamond trade seem to be about reducing overall impact (recycled and lab-created) and/or increasing traceability (Canadian, Russian and Australian diamonds), although there is a significant development diamond narrative that has buoyed demand for diamonds from countries such as Botswana, Namibia and South Africa, and DeBeers is positioning those same countries to meet traceability demands as well. While these market movements have been steered by the largest diamond producers and retailers, there is still a vocal minority of retailers, designers, and consumers pursuing what we might call a fair trade model, if not a true solidarity agenda, as seen in other ethical markets as well. These "mission-driven" (Raynolds, 2009) pursuits are visible as blips in the market evolution figures and tables above. For instance, Lesotho and Sierra Leone have both figured in the ethical diamond market, with $12 \%$ of ethical diamond retailers promoting Lesotho in 2009 , second only to Canada in terms of countries of origin, and tied for third with recycled diamonds in terms of all ethical diamond types (after Canada and lab-created; see Table 1.0).

How did the tiny nation of Lesotho gain this impressive market share, and how did it lose it? (There are not currently any ethical diamond retailers marketing diamonds from Lesotho.) As shown in Table 2.0, Lesotho is $10^{\text {th }}$ in the world for overall diamond production, and $7^{\text {th }}$ in terms of US dollar value. The story of Lesotho's rise as an ethical source for diamonds is really the story of a single mining cooperative. The Liquobong Diamond Mining Cooperative operated for decades under quasi-state control and funding, but operations have since been taken over by a Canadian multinational (Makhetha, 2017). The cooperative, whose diamond miners were largely women nearing retirement, was looking to increase their returns by skirting the DeBeers monopoly, and their diamonds eventually made their way to the ethical diamond market through a German geologist and ethical sourcing consultant. ${ }^{26}$ It was a particularly popular source among the mission-driven sub-market because it met many of the conditions that they list when asked about their ideal diamond source: from an artisanal mining cooperative, from Africa, with clear traceability (i.e. could visit the source community), although the diamond concession's sale to the Canadian multinational means it is no longer a source for artisanal, fairly traded stones. What 
is important here is that while there has been successful discursive contestation of Canada's ethical monopoly and the acceptance of a fair trade ideal amongst a sub-set of mission-driven organizations, this shift in demand has not been met by supply. In the words of one interviewee: "We had a few diamonds from Lesotho, and I thought that was a really nice project but ... it's been very difficult, at least in Africa, to find, to replicate that" (wholesale diamond dealer, personal interview, 9/14/17).

As Hilson et al. (2016) have argued, most fair trade schemes target the already-organized (cooperatives, etc.) -- communities that they can easily connect to, rather than having to organize from the ground up. In their words, "In the rare instance where genuine efforts are being made to partner with marginalized operators, the most illustrative example being the Development Diamond Standards pilot project in Sierra Leone, the absence of 'supportive' development policy could prove too formidable to overcome, and consequently, force a move to link with a more reachable, well-established operator" (Hilson et al., 2016: 29-30). Indeed, the blips from Sierra Leone seen in the figures and tables above, are the result of such "linking up" with wellestablished operators. After years of laying the groundwork and developing a set of fair trade standards (the Maendeleo Diamond Standards) but being unable to develop a clear route to market, the Diamond Development Initiative (DDI), a non-profit organization working on sustainable community development within the artisanal and small-scale mining sector, has partnered with DeBeers. Through its GemFair program, ${ }^{27}$ the partnership's first diamonds from Sierra Leone are finally making it to market.

These blips are important to understand because they reveal both a set of opportunities (unmet demand for fairly traded artisanal diamonds), but also the supply-side difficulties of meeting that demand. I think that Dempsey and Pratt's (2019) "wiggle room" metaphor is useful here. In their words (2019: 275),

Wiggle room is at once a recognition of these cramped spaces, the material constraints, the structuring logics of patriarchy, racism, the incessant drive to accumulation, and the something more. The room we are thinking of is not a space outside of hegemonic power relations. Rather, by wiggle room we emphasise the always present "traces" ... and possibilities for being otherwise within those relations.

In the case of the ethical diamond market, the efforts to develop fairly traded alternatives to the big ethical product havens that dominate the supply continue, but seeing them as constrained by and in relation to these bigger logics and power players provides an important context. This context could lead some stakeholders to new efforts to develop alternative wholesale ventures, and others to redirect their political activities away from consumer-led ethical product markets and toward other advocacy targets, including World Bank and national mineral and related development policies.

\section{Conclusion}


The Wayback Machine has proven to be a useful new tool for reconstructing market evolution when other measures of market share and firm behavior are not available. We argue that it is important to understand ethical production spaces in relation to each other, and to capture the competitive dynamics and power relations that evolve over time in order to evaluate the markets' governance outcomes, future potential, and limitations. In this case, the data reveals that there has been considerable contestation within the ethical diamond market, with the emergence of new ethical product havens to counter Canada's early monopoly and the rapid ascent of synthetic (most often marketed as lab-created or lab-grown) diamonds. Despite these significant market movements -including the important corrective to over-generalized associations of Africa with violent, diamond-fueled conflict, the trends mirror those found in other ethical markets such as the certified forest products market (Cashore et al., 2007; Abrams et al., 2018). As discussed above, the "winners" in these markets are generally countries where existing regulations largely meet the social and/or environmental criteria set by the ethical sub-market. Moreover, for industries where production (and hence power) is concentrated in the hands of a few large players, they are able to more easily control the terms of certification and competition (Havice and Campling, 2017). For the ethical diamond market, the big industrial diamond producers have coalesced around traceability to country of origin, benefitting Russia, South Africa, Botswana, Namibia and Australia, in addition to Canada.

Given the origins of the ethical diamond market in relation to the conflict diamond issue, one could argue that the market should be serving those countries and communities most affected by the conflict diamond trade, which is clearly not the case. One could also argue, then, that the ethical diamond market is not achieving much in terms of governance. As Schlosser (2013: 176) notes: "ethical consumption deployed in this way increasingly defers to a self-congratulatory system of identification". If the biggest governance change is traceability to country of origin, that, in and of itself, is unlikely to increase community returns. When the information made public is limited to country of origin rather than specific mines, this limits the ability of NGOs and community members to mobilize consumer and broader public pressure to address minespecific controversies. Moreover, as long as synthetic diamond producers are able to maintain a category-wide perception of sustainability and "doing the least harm" (see Table 2.0), this limits the ability to pressure them to address energy use, labor conditions, and other factory differentiators. Despite the big new marketing efforts and philanthropic initiatives (e.g. the Diamonds Do Good campaign), the social and environmental conditions of production have not been significantly improved by the ethical market.

And yet, contestation continues. There are now a number of new standards emerging, particularly due to the now heated battle between the synthetic and mined sub-sectors. For instance, the recently formed Lab Grown Diamond Council is working with global standards and certification consulting firm SCS Global Services to develop a sustainability standard, and the Initiative for Responsible Mining Assurance (IRMA) has developed a Standard for Responsible Mining and an associated mine certification process. ${ }^{28}$ It is clear not only from this project but from the now substantial body of social science research on market- and consumer-oriented governance discussed above, that certification often marginalizes smaller producers and lower- 
income countries, so there should be attention paid to how these new standards might affect different diamond producing communities. Additional work is needed to understand whether they will serve to simply secure existing ethical product havens, and/or whether they can improve some of the social and environmental conditions of production within the industry. And this research shows it is also necessary to allow for the possibility that the stone that does "the most good" may in some cases be an uncertified stone purchased directly from an artisanal diamond mining cooperative or a diamond trader with long-standing ties to producing communities. Finally, the search for the most ethical stone (or coffee bean or hardwood flooring) obscures the fact that rights-based approaches (focused on rights to land, to resources, to mineral returns, to cultural preservation, to ecological functioning, and more) are needed to address the needs of the most marginalized producers, and to enable communities to secure alternative livelihoods and land attachments, rather than just negotiate the terms of extraction.

\section{References}

Abrams J, Nielsen E, Diaz D, Selfa T, Adams E, Dunn JL and Moseley C (2018) How do states benefit from nonstate governance? Evidence from forest sustainability certification. Global Environmental Politics 18(3): 66-85.

Ainsworth S, Nelson M and Van de Sompel H (2015) Only one out of five archived web pages existed as presented. Proceedings of the 26th ACM Conference on Hypertext \& Social Media: 257-266.

Angel D, Hamilton T and Huber, M (2007) Global environmental standards for industry. Annual Review of Environment \& Resources 32: 295-316.

Anholt S (2006) Brand new justice. Routledge.

Arora S, Li Y, Youtie J and Shapira P (2016) Using the wayback machine to mine websites in the social sciences: a methodological resource. Journal of the Association for Information Science and Technology 67(8): 1904-1915.

Atela J, Quinn C and Minang P (2014) Are REDD projects pro-poor in their spatial targeting? Evidence from Kenya. Applied Geography 52: 14-24.

Auld G (2010) Assessing certification as governance: effects and broader consequences for coffee. The Journal of Environment \& Development 19(2): 215-241.

Autio M, Heiskanen E, and Heinonen V (2009) Narratives of 'green' consumers -- the antihero, the environmental hero and the anarchist. Journal of Consumer Behaviour 8: 40-53.

Bair J and Werner M (2011) Commodity chains and the uneven geographies of global capitalism: A disarticulations perspective. Environment and Planning A 43: 988-997.

Bidwell S, Murray W and Overton J (2018) Ethical agro-food networks in global peripheries, Part I: The rise and recommodification of fair trade and organics. Geography Compass 12(4): 
Benson P and Fischer EF (2007) Broccoli and desire. Antipode 39: 800-820.

Bielawski E (2004) Rogue diamonds: Northern riches on Dene land. University of Washington Press.

Blazquez D, Domenech J and Debón A (2018). Do corporate websites' changes reflect firms' survival? Online Information Review 42(6): 956-970.

Brach S, Walsh G and Shaw D (2018) Sustainable consumption and third-party certification labels: Consumers' perceptions and reactions. European Management Journal 36(2): 254-265.

Bridge G (2004) Mapping the bonanza: geographies of mining investment in an era of neoliberal reform. The Professional Geographer 56(3): 406-421.

Bryant R and Goodman M (2004) Consuming narratives: the political ecology of 'alternative' consumption. Transactions of the Institute of British Geographers 29: 344-366.

Carrigan M, Marinova S, Szmigin I, De Pelsmacker P, Janssens W, Sterckx E and Mielants C (2005) Consumer preferences for the marketing of ethically labelled coffee. International marketing review 22(5): 512-530.

Cashore B, Auld G, Bernstein S and McDermott C (2007) Can non-state governance 'ratchet up'global environmental standards? Lessons from the forest sector. Review of European Community \& International Environmental Law 16(2): 158-172.

Clarke N, Barnett C, Cloke P and Malpass A (2007) Globalising the consumer: Doing politics in an ethical register. Political Geography 26(3): 231-249.

Corbera E and Brown K (2010) Offsetting benefits? Analyzing access to forest carbon. Environment and Planning A 42(7): 1739-1761.

Crane A (2001) Unpacking the ethical product. Journal of Business Ethics 30(4): 361-373.

Curty R and Zhang P (2011) Social commerce: Looking back and forward. Proceedings of the American Society for Information Science and Technology 48(1): 1-10.

Dempsey J and Pratt G. (2019) Wiggle Room. In: Antipode Editorial Collective (eds.) Keywords in Radical Geography: Antipode at 50. Wiley Blackwell.

Hashim NH, Murphy J and O'Connor P (2007) Take me back: validating the wayback machine as a measure of website evolution. Information and Communication Technologies in Tourism 2007: 435-446.

Falls S (2011) Picturing blood diamonds. Critical Arts 25(3): 441-466.

Freidberg S (2003) Cleaning up down South: supermarkets, ethical trade and African horticulture. Social \& Cultural Geography 4: 27-43. 
Goodman M (2010) The mirror of consumption: Celebritization, developmental consumption and the shifting cultural politics of fair trade. Geoforum 41: 104-116.

Gregory D (2011) Geographical imaginary. In: Gregory D, Johnston R, Pratt G, Watts M and Whatmore, S. The dictionary of human geography. John Wiley \& Sons.

Hamilton T (2011) Putting corporate responsibility in its place. Geography Compass 5: 710-722.

Havice E and Campling L (2017) Where chain governance and environmental governance meet: Interfirm strategies in the canned tuna global value chain. Economic geography 93(3): 292-313.

Johnson A. (2014) Ecuador's national interpretation of the Roundtable on Sustainable Palm Oil (RSPO): green-grabbing through green certification? Journal of Latin American Geography 13(3): 183-204.

Le Billon P (2006) Fatal transactions: conflict diamonds and the (anti) terrorist consumer. Antipode 38: 778-801.

Le Billon P (2008) Diamond wars? Conflict diamonds and geographies of resource wars. Annals of the Association of American Geographers 98(2): 345-372.

Levy D and Prakash A (2003) Bargains old and new: Multinational corporations in global governance. Business and politics 5(2): 131-150.

Li Y, Arora S, Youtie J and Shapira P (2018). Using web mining to explore Triple Helix influences on growth in small and mid-size firms. Technovation 76: 3-14.

Makhetha E (2017) The rise and fall of Liqhobong Diamond Mine Cooperative in Lesotho. Anthropology Southern Africa 40(3): 185-196.

Murphy J, Noor HH, and O'Connor P (2007) Take Me Back: Validating the Wayback Machine, Journal of Computer-Mediated Communication 13(1): 60-75.

McEwan C, Hughes A and Bek D (2015) Theorising middle class consumption from the global South: A study of everyday ethics in South Africa's Western Cape. Geoforum 67: 233-243.

Micheletti M and Stolle D (2006) Politics, products, and markets: Exploring political consumerism past and present. Piscataway, NJ: Transaction publishers.

Missens R, Dana LP, and Anderson R (2007) Aboriginal partnerships in Canada: Focus on the Diavik diamond mine. Journal of Enterprising Communities: People and Places in the Global Economy 1: 54-76.

Nadvi K (2008) Global standards, global governance and the organization of global value chains. Journal of economic geography 8(3): 323-343. 
Nadvi K and Wältring F (2004) Making sense of global standards. In: Schmitz H (ed.) Local Enterprises in the Global Economy. Cheltenham: Edward Elgar.

Nel E, Binns T and Bek D (2007) 'Alternative foods' and community-based development: Rooibos tea production in South Africa's West Coast Mountains. Applied Geography 27(2): 112-129.

Peeters S and Gilmore AB (2014) Understanding the emergence of the tobacco industry's use of the term tobacco harm reduction in order to inform public health policy. Tobacco control 24(2): 182-189.

Popke J (2006) Geography and ethics: everyday mediations through care and consumption. Progress in Human Geography 30(4): 504-512.

Raynolds LT (2009) Mainstreaming fair trade coffee: From partnership to traceability. World development 37(6): 1083-1093.

Raynolds L and Ngcwangu S (2010) Fair trade Rooibos tea: connecting South African producers and American consumer markets. Geoforum 41(1): 74-83.

Renard, MC (2005) Quality certification, regulation and power in fair trade. Journal of rural studies 21(4): 419-431.

Schlosser K (2013) Regimes of Ethical Value? Landscape, Race and Representation in the Canadian Diamond Industry. Antipode 45(1): 161-179.

Schroeder R (2010) Tanzanite as conflict gem: certifying a secure commodity chain in Tanzania. Geoforum 41(1): 56-65.

Smith E (2012) Corporate image and public health: an analysis of the Philip Morris, Kraft, and Nestle websites. Journal of health communication 17(5): 582-600.

Whitelaw G, McCarthy D, and Tsuji L (2009) The Victor Diamond Mine environmental assessment process: a critical First Nation perspective. Impact Assessment and Project Appraisal 27: 205-215.

Youtie J, Hicks D, Shapira P and Horsley T (2012) Pathways from discovery to commercialisation: using web sources to track small and medium-sized enterprise strategies in emerging nanotechnologies. Technology Analysis \& Strategic Management 24(10): 981-995.

\footnotetext{
1 We use scare quotes here to clarify that we are not making or supporting any claims about products' actual ethical credentials when we use the term ethical throughout the article.

${ }^{2}$ While the category of conflict diamonds refers specifically to countries where "rough diamonds [are] used by rebel movements to finance wars against legitimate governments" (kimberleyprocess.com), the whole continent has often been marked as an unethical source, particularly when contrasted with Canada.
} 
${ }^{3}$ https://www.palgrave.com/gp/journal/41254

4 https://www.debeersgroup.com/the-group/about-debeers-group/brands/a-diamond-is-forever

5 https://www.kimberleyprocess.com/en/what-kp

6 https://www.kimberleyprocess.com

7 https://www.npr.org/templates/story/story.php?storyld=96564952

8 Debates often reference the whole continent rather than individual countries.

${ }^{9}$ See, for instance: https://reflectivejewelry.com/ethical-sources/ethical-diamond-choices

10 This is not to be confused with synthetic alternatives such as cubic zirconia; synthetic diamonds have the same chemical and physical properties as mined diamonds. We use lab-created throughout the paper as that (along with lab-grown) is the most commonly used term within the industry, although we recognize that it can obscure the actual nature of production, which is really factory production.

${ }^{11}$ See the Jewelry Glossary Project for detailed discussion of the different types of recycled stones: https://jewelryglossaryproject.com/

$12 \mathrm{http}: / /$ archive.org/about/

${ }^{13}$ We conducted a first round of this analysis in with data until 2015 and then updated it at the end of 2019 following the same methods. We chose to update the data because of the rapid pace of chance that we were witnessing within the market as the research progressed.

14

https://www.bain.com/contentassets/e225bceffd7a48b5b450837adbbfee88/bain_report_global_diamond_ report_2019.pdf

${ }^{15}$ We included this search term even though it is largely associated with Kimberley Process compliance because it is also used to market additional ethical credentials.

${ }^{16}$ As discussed above, these numbers are based on our method of identifying firms with an Englishlanguage web presence that have positioned themselves as ethical diamond retailers and that sell to the US, Canadian and UK buyers.

17 There is a lot more to say about these ethical orientations and narratives, including their evolution over time and their differentiation across different venues and market actors. These details will be elaborated in future publications.

$18 \mathrm{https}: / /$ www.diamondsdogood.com/who-we-are/

19 There is a broad differentiation of the marketing of Canadian and African-origin diamonds, but there are examples where development narratives, particularly colonial development narratives in relation to Indigenous communities' livelihood opportunities, are used to market Canadian diamonds as well (see Schlosser 2013). Our own analysis found these development narratives in only a small percentage of Canadian diamond marketing, although they are undoubtedly more prevalent in development and mineral policy discourse.

${ }^{20}$ www.dtc.com

${ }^{21}$ https://www.nationaljeweler.com/blog/7362-de-beers-has-changed-this-rule-regarding-rough-diamonds

22 https://www.miningglobal.com/technology/alrosa-joins-forces-de-beers-group-tracr-blockchain-platform

${ }^{23} \mathrm{https}: / / w w w . b a i n . c o m / i n s i g h t s / g l o b a l-d i a m o n d-i n d u s t r y-r e p o r t-2018 / \#$

24 https://www.diamonds.net/News/Newsltem.aspx?ArticlelD=63916\&ArticleTitle=JCK+LabGrown+Section+Shows+Rising+Demand

25 https://ecocult.com/lab-grown-diamonds-ethical-sourcing-conflict-free/

26 http://www.faire-edelsteine.de/17.0.html

27 https://gemfair.com/

${ }^{28}$ https://www.scsglobalservices.com/news/lab-grown-diamond-council-retains-scs-global-services-todevelop and https://responsiblemining.net/ 